\title{
EFL Students' Writing Anxiety in Online Learning Environment during the Covid-19 Pandemic
}

\author{
Kurniasih Kurniasih ${ }^{1,2}$, Bambang Yudi Cahyono ${ }^{3 *}$, Utari Praba Astuti ${ }^{3}$, and Nunung \\ Suryati ${ }^{3}$
}

\author{
${ }^{1}$ Doctorate Program in ELT Faculty of Letters, Universitas Negeri Malang, Indonesia \\ ${ }^{2}$ Department of English, Faculty of Teacher Training and Education, Universitas Islam Malang \\ ${ }^{3}$ Department of English, Faculty of Letters, Universitas Negeri Malang, Indonesia \\ *Corresponding author.Email: bambang.yudi.fs@um.ac.id
}

\begin{abstract}
Research on writing anxiety has been widely done in an offline setting for many years. The results informed that students were at various levels of writing anxiety. Due to the global pandemic, language classrooms have been shifted into emergency remote learning. It is susceptible that students also experience writing anxiety in an online learning environment. This study investigates the students' writing anxiety in an online setting. More specifically, it investigates the the levels and types of writing anxiety across gender. This study involved 215 EFL students from three universities in Indonesia. The SLWAI questionnaire was distributed via Google. The obtained data were analyzed using an independent sample t-test to figure out the difference and levels and types of writing anxiety across gender. The findings showed that EFL students experience writing anxiety in an online setting. The results showed that both groups had moderate anxiety levels. Female students' average score (63.81) was slightly higher than male students (62.01). Statistical analysis showed that no statistical difference was observed in levels of anxiety across gender. In addition, male and female students experienced somatic anxiety, cognitive, and avoidance behavior. Cognitive anxiety and avoidance behavior anxiety were at moderate levels; however, the two groups experienced higher somatic anxiety in online writing activities. This indicates that students had unpleasant feelings as a result of the anxiety experienced.
\end{abstract}

Keywords: gender, levels of anxiety, online writing class, types of anxiety, writing anxiety

\section{INTRODUCTION}

Writing is undoubtedly a demanding skill for students in EFL context to acquire [1], [2]. Hyland [3] claimed that mastering writing skill is challenging for second language learners because writing is far more challenging than the other three skills, listening, speaking, and reading [4]. People acquire a negative attitude toward writing and so suffer from writing anxiety as a result of the complicated procedures required in writing, which is considered more challenging in terms of learning than other language skills [5]. Lack of grammatical understanding and vocabulary mastery are common problems for lowproficiency writers while writing. Meanwhile, high proficiency students struggle with creating coherent essays and using correct grammar when writing[6]. Furthermore, students found difficulties in writing due to the complexity of English structure and low writing skills.
Many factors make learning a second/foreign language difficult, such as personality, attitude, perception, motivation, and emotions [7]. An affective factor, in this case, anxiety, inhibits learners from enhancing their abilities when studying English [8] Anxiety will likely happen in receptive skills (Reading and Listening) and productive skills (Writing and Speaking) [2]. Based on the result of the Foreign Language Anxiety (FLA) meta-analysis, writing anxiety and listening anxiety were found to contribute more effect on achievement compared to reading and speaking anxiety [9]. However, FLA is a common phenomenon and is perceived to be a detrimental factor in learning a language [10]. Horwitz et al. [11] associated FLA with an emotional state when students are required to use the target language, take tests and are afraid of negative comments from others. They elaborated FLA occurs due to one's perception, beliefs, emotions, and attitudes about learning a language as a result of the uniqueness of the process of language learning [11]. EFL learners found it difficult to express 
ideas due to writing anxiety because they fail in controlling their self-efficacy in writing[12].

The attention of language learning research changes from the dominance of cognitive perspective to the role of emotion due to its crucial role in determining the student's success. Emotion in language learning is the heart of language teaching [13]. Chuang [14] associated emotions with Language Anxiety (LA). Most of the studies on anxiety examined the levels and types of anxiety ([1], [15], [16]. The findings of those studies found that students were highly anxious when they are assigned to write. Meanwhile, [17] found sophomore, junior, and senior students experienced moderate levels of anxiety. Scholars have found that writing anxiety contributes to students' low writing performance [18], [19]. They reported that writing anxiety has a negative relationship with the students' writing ability [18], [20]. This means that students who have low anxiety have good writing performance. Concerning gender, female students were found to feel more anxious in writing than male counterpart [21], [22] but the difference is not significant[1][23].

Cheng [24] classifies writing anxiety into three types namely somatic anxiety, cognitive anxiety, and avoidance behavior. First, Somatic Anxiety refers to physiological reactions which can be observed such as trembling, sweaty, heart pounding, panic). Cognitive Anxiety refers mental chages or psychological components (worry, anxiety, fear). The while Avoidance Behavior represents an act of avoiding writing activities due to negative feelings. Most scholars have found that cognitive anxiety was commonly encountered by language learners ([1], [15], [16], [18]

There are plenty of online platforms that are used by teachers to conduct online writing instruction, such as Google Classroom, Zoom, and WhatsApp. Some scholars have used Edmodo ([2 5], Flip classroom [26], and Google.doc[27]. Even though some studies suggest that online learning enhances students' participation and motivation [26], [28]. Investigating affective factors, especially anxiety in an online writing class add more empirical findings on the students' writing anxiety in online class during the global outbreak by referring to figure the significant difference of levels and types of writing anxiety across gender. Gender is considered important when discussing language anxiety [29]. Furthermore, the previous studies were conducted in an offline setting; however, there is still room for investigation since it is susceptible that students also experience writing anxiety in an online learning environment. This study aims at answering two research questions:
a. Is there any significant difference in level of writing anxiety across gender?
$b$. Is there any significant difference in types of writing anxiety across gender?

\section{METHOD}

To answer the research questions, the current study employed a quantitative design involving 215 English students from three universities in Indonesia. It consists of 64 male and 151 female students. The participants were in their second to third year of study. They have taken paragraph and essay writing in their study. This study employed Cheng's (2004) questionnaire, called Second Language Writing Anxiety Inventory (SLWAI) [24]. The SLWAI (22 items) falls into three categories: Somatic Anxiety $(19,15,13,11$, 8, 6, 2), Cognitive Anxiety $(21,20,17,14,9,7,3,1)$, and Avoidance Behavior $(22,18,16,12,10,5,4)$.

This questionnaire consists of five points, 5 (strongly agree), 4 (agree), 3 (undecided), 2 (disagree), and 1 (strongly disagree). Five items $(1,4,17,18,22)$ in the questionnaire are written in negative statements. So, reverse scoring was carried out prior to calculating the total score. The SLWAI was turned into an online questionnaire through a google form. To measure writing anxiety levels, the students' responses was calculated to find the mean. The maximum possible score of each participant is 110 and the minimum possible score is 22 . The levels of anxiety were low $(M=<50)$, moderate $(M=50-65)$, and high $(M=>65)$. Further analysis was intended to categorize the students' anxiety types into cognitive, somatic, and avoidance behavior. Statistical analysis, an independent sample ttest, was also performed to figure out the levels and types of students' anxiety across gender.

\section{FINDINGS}

Is there any significant difference in levels of writing anxiety across gender?

Table 1.1 below presents information that there are 64 male students and 151 female students. The result of descriptive analysis from the SLWAI questionnaire depicted that the male students reported a mean score of 62.01 , and the mean score of female students is slightly higher (63.81). Both means indicate that the level of writing is moderate since the means are less than 65 . It can be said that both female and male students suffer moderate anxiety levels in writing activities during the online setting.

Table1. The Descriptive Statistics of Participants Information

\begin{tabular}{|l|l|r|c|c|c|}
\hline & Gender & N & Mean & Std. Deviation & \multicolumn{1}{c|}{ Std. Error Mean } \\
\hline Anxiety Score & Male & 64 & 62.02 & 7.13673 & .89209 \\
& Female & 151 & 63.81 & 7.30435 & .59442 \\
\hline
\end{tabular}

Table 2 presents the result of the statistical analysis to examine the significant difference between writing anxiety levels across gender. The mean difference is
1.79383 with the level of significant .099. Anxiety levels for male and female students have no statistical difference because the level of significance is higher than .05 . 
Table 2. The difference in overall levels of anxiety levels across gender

\section{Mean Difference}

Sig. (2-tailed)

Writing Anxiety Score

$-1.79385$

.099

Is there any significant difference in types of anxiety across gender?

Further analysis showed that male and female students experienced somatic, cognitive, and avoidance behavior. For somatic anxiety, male students obtain 66.29 for the average score, while female students have a higher average score $(M=69.25)$. The mean score of cognitive anxiety for male is 61.40 and 61.34 for female students. The results revealed that the female suffered higher anxiety $(\mathrm{M}=60.59)$ and the male counterpart (58.21) for the score of Avoidance Behavior anxiety. In general, both groups have moderate anxiety for cognitive anxiety and avoidance behavior anxiety; however, the two groups have a higher mean in somatic anxiety (see Table 3 ).

Table 3. The descriptive statistics of types of anxiety across gender

\begin{tabular}{|c|c|c|c|c|c|}
\hline \multirow{3}{*}{ Cognitive Anxiety } & Gender & $\mathrm{N}$ & Mean & Std. Deviation & $\begin{array}{l}\text { Std. Error } \\
\text { Mean }\end{array}$ \\
\hline & Male & 64 & 61.40 & 8.65 & 1.08 \\
\hline & Female & 151 & 61.34 & 8.346 & .679 \\
\hline \multirow[t]{2}{*}{ Somatic Anxiety } & Male & 64 & 66.29 & 12.102 & 1.51 \\
\hline & Female & 151 & 69.25 & 11.92 & .97 \\
\hline \multirow{2}{*}{$\begin{array}{l}\text { Avoidance } \\
\text { Behavior }\end{array}$} & Male & 64 & 58.21 & 7.33 & .92 \\
\hline & Female & 151 & 60.59 & 8.85 & .72 \\
\hline
\end{tabular}

Table 4. reports the results of statistical analysis using an Independent sample t-test to examine the difference in three categories of anxiety across gender.
The significance level for cognitive anxiety was .959 , while for somatic anxiety was .099 , and .61 for avoidance behavior. The overall level of significance was higher than .05 indicating that the difference in the type of anxiety across gender is not significant.

Table 4. The difference in overall types of anxiety levels across gender

\begin{tabular}{lcc}
\multicolumn{1}{c}{ Categories } & Mean Difference & Significance (2-tailed) \\
\hline Cognitive Anxiety & .06519 & .959 \\
Somatic Anxiety & -2.95827 & .099 \\
Avoidance Behavior & -2.37209 & .061 \\
\hline
\end{tabular}

\section{DISCUSSION}

Writing anxiety is believed to be a crucial element in second language acquisition. Some empirical studies showed that writing anxiety has a negative relationship with students writing ability. Research studies have proved that anxious students have poor writing performance ([18], [20]. Due to the detrimental effects of writing anxiety, it is necessary to examine the levels and types of anxiety in an online setting encountered by EFL students in Indonesia during the Covid-19 pandemic. The findings indicate that the mean score of female $(M=63.8)$ and male $(M=62)$ students indicated moderate writing anxiety levels since it is lower than $<65$.

During the covid-19 pandemic, all language instructions are turned into online learning. The current study showed different results of the studies on writing anxiety in an offline setting. In this study, both male and female students experience moderate anxiety. The results of this study are in agreement with the results of the previous studies [17]. Conversely, the findings of this study are different from studies that found most students were highly anxious in writing activity [16], [30]. Concerning gender analysis, this study supports the finding of studies ([1], [21], [22] which show that male students were less anxious than female students, but they were not significantly different [23], [31]. However, this study is also inconsistent with some studies [32], [33] that male participants experienced a relatively higher anxiety level. The gender effect on writing anxiety varied from one situation to another, which may be influenced by some factors, such as linguistics problems and lack of vocabulary [3], inadequate knowledge of writing aspects (mechanic, content, writing organization [34], and lack of writing practice [35]

The descriptive analysis of anxiety types revealed that both male and female students suffered high somatic anxiety with an average score of 68 . Students showed unpleasant feelings as a result of anxiety experience which refers to bodily symptoms, such as feeling nervous and tension that could occur 
when they experienced anxiety. Meanwhile, both groups have moderate levels of cognitive anxiety and avoidance behavior anxiety. These findings are different from most of the studies conducted in the offline setting ([1], [15], [16]. Those studies found that students experience cognitive anxiety; they feel anxious due to negative mental processes such as being afraid of receiving negative comments from peers and teachers [24]. Thus, a low level of anxiety is necessary for EFL students to be more attentive with their English use, but too much tension will negatively affect their ability and cause serious problems [36]. From this study, it can be understood that writing anxiety exist in the online classroom, and it is expected that teachers accommodate students' emotions and find best teaching strategies to reduce students' anxiety, so that they will be more motivated to write English compositions.

\section{CONCLUSION}

The current study aims at investigating the difference in levels and types of writing anxiety across gender. The first interesting result of this research is that both female and male students experience somatic anxiety during the online writing classes. However, the finding deviates from most of the previous studies on writing anxiety. The second finding revealed students' moderate level of anxiety which is different from studies examining writing anxiety in a face-to-face class. There seems to be a shifting phenomenon from the dominance of cognitive anxiety to the dominance of somatic anxiety in the online setting in which students are nervous, have fast heart-beat, feel blank, and feel confused when they start writing composition under time constraints. A further in-depth study using interviews could focus on high anxious students in the online writing class.

\section{AUTHORS' CONTRIBUTIONS}

All the authors have equal roles in completing this article. The authors have written the report and proofread the manuscript.

\section{ACKNOWLEDGMENTS}

The authors express their gratitude to The Directorate of Research and Community Service - Ministry of Research, Technology and Higher Education (MoECRT 2021), Republic Indonesia for providing the financial support of the research.

\section{REFERENCES}

[1] Y. Cheng, "Factors Associated with Foreign Language Writing Anxiety," Foreign Lang. Ann., vol. 35, no. 6, pp. 647-656, Nov. 2002, doi: 10.1111/j.1944-9720.2002.tb01903.x.

[2] P. D. MacIntyre and R. C. Gardner, "Methods and Results in the Study of Anxiety and Language Learning: A Review of the Literature*," Lang. Learn., vol. 41, no. 1, pp. 85-117, Mar. 1991, doi: 10.1111/j.1467-1770.1991.tb00677.x.
[3] K. Hyland, Second Language Writing. Cambridge University Press, 2003.

[4] N. S. M. Daud, N. M. Daud, and L. N. A. Kassim, "Second language writing anxiety: Cause or effect?" Malaysian Journal of ELT Research, Inaugural.

Retrieved fromhttp://www.melta.org.my/Doc/second_lang_w riting_anxiety.pdf.

[5] T. Turkben, "The Relationship Between Fifth Grade Student's Writing Anxiety And Blocking With Their Written Expression Skills," Int. Online J. Educ. Teach. IOJET, vol. 8, no. 2, pp. 998-1021.

[6] R. Bruning and C. Horn, "Developing Motivation to Write," Educ. Psychol., vol. 35, no. 1, pp. 25-37, Mar. 2000, doi: 10.1207/S15326985EP3501_4.

[7] S. Aydin, "An Investigation on the Language Anxiety and Fear of Negative Evaluation among Turkish EFL Learners," Asian EFL J., pp. 421444, 2008.

[8] T. Talib Ali and W. Fook Fei, "Foreign Language Classroom Anxiety among Iraqi Students and its Relation With Gender and Achievement," Int. J. Appl. Linguist. Engl. Lit., vol. 6, no. 1, p. 305, Nov. 2016, doi: 10.7575/aiac.ijalel.v.6n.1p.305.

[9] Y. Teimouri, J. Goetze, and L. Plonsky, "SECOND LANGUAGE ANXIETY AND ACHIEVEMENT: A META-ANALYSIS," Stud. Second Lang. Acquis., vol. 41, no. 2, pp. 363-387, May 2019, doi: $10.1017 / \mathrm{S} 0272263118000311$.

[10] M. Byram and A. Hu, Eds., Routledge Encyclopedia of Language Teaching and Learning, 1st ed. Routledge, 2013. doi: 10.4324/9780203101513.

[11] E. K. Horwitz, M. B. Horwitz, and J. Cope, "Foreign Language Classroom Anxiety," Mod. Lang. J., vol. 70, no. 2, pp. 125-132, Jun. 1986, doi: 10.1111/j.1540-4781.1986.tb05256.x.

[12] M. Ho, "Exploring Writing Anxiety and SelfEfficacy among EFL Graduate Students in Taiwan," High. Educ. Stud., vol. 6, no. 1, p. 24, Dec. 2015, doi: 10.5539/hes.v6n1p24.

[13] J.-M. Dewaele, X. Chen, A. M. Padilla, and J. Lake, "The flowering of positive psychology in foreign language teaching and acquisition research," Front. Psychol., vol. 10, p. 2128, 2019.

[14] C.-H. Chuang, "University Teachers' Strategies for Alleviating EFL Learner Anxiety," J. Asia TEFL, vol. 16, no. 2, p. 691, 2019.

[15] M. Jennifer and R. J. Ponniah, "Investigating the Levels, Types and Causes of Second Language Writing Anxiety among Indian Freshmen," $J$. Asiat., vol. 14, no. 3, pp. 557-563, Sep. 2017, doi: 10.18823/asiatefl.2017.14.3.13.557.

[16] R. Kusumaningputri, T. A. Ningsih, and W. Wisasongko, "Second Language Writing Anxiety of Indonesian EFL Students," Lingua Cult., vol. 12, no. 4, p. 357, Nov. 2018, doi: 10.21512/lc.v12i4.4268.

[17] D. W. Delvi Wahyuni, W. O. Witri Oktavia, and L. M. Leni Marlina, "Writing Anxiety among 
Indonesian EFL College Students: Levels, Causes, and Coping Strategies," Lingua Cult., vol. 13, no. 1, p. 67, Apr. 2019, doi: 10.21512/lc.v13i1.5239.

[18] D. Y. Erkan and A. İ. Saban, "Writing performance relative to writing apprehension, self-efficacy in writing, and attitudes towards writing: A correlational study in Turkish tertiary-level EFL," Asian EFL J. Q. March 2011 Vol. 13 Issue, vol. 13, no. 1, pp. 164-192, 2011.

[19] M. Gibriel, "Investigating Writing Strategies, Writing Anxiety and Their Effects on Writing Achievement: A Mixed Method Design," J. Asiat., vol. 16, no. 1, pp. 429-436, Mar. 2019, doi: 10.18823/asiatefl.2019.16.1.33.429.

[20] C. T. Martinez, N. Kock, and J. Cass, "Pain and pleasure in short essay writing: Factors predicting university students' writing anxiety and writing self-efficacy," J. Adolesc. Adult Lit., vol. 54, no. 5, pp. 351-360, 2011.

[21] S. Abu-Rabia *, “Teachers' Role, Learners' Gender Differences, and FL Anxiety Among Seventh-Grade Students Studying English as a FL," Educ. Psychol., vol. 24, no. 5, pp. 711-721, Sep. 2004, doi: 10.1080/0144341042000263006.

[22] N. A. Razak, A. A. Yassin, and T. N. R. B. T. Mohamad Maasum, "Effect of Foreign Language Anxiety on Gender and Academic Achievement among Yemeni University EFL Students," Engl. Lang. Teach., vol. 10, no. 2, p. 73, Jan. 2017, doi: 10.5539/elt.v10n2p73.

[23] Y. Aida, "Examination of Horwitz, Horwitz, and Cope's Construct of Foreign Language Anxiety: The Case of Students of Japanese," Mod. Lang. J., vol. 78, no. 2, pp. 155-168, Jun. 1994, doi: 10.1111/j.1540-4781.1994.tb02026.x.

[24] Y.-S. Cheng, "A measure of second language writing anxiety: Scale development and preliminary validation," J. Second Lang. Writ., vol. 13, no. 4, pp. 313-335, Dec. 2004, doi: 10.1016/j.jslw.2004.07.001.

[25] F. Yavuz, E. Ozdemir, and O. Celik, "The effect of online gamification on EFL learners' writing anxiety levels: a process-based approach," World J. Educ. Technol. Curr. Issues, vol. 12, no. 2, pp. 6270, Apr. 2020, doi: 10.18844/wjet.v12i2.4600.

[26] W.-C. V. Wu, J. C. Yang, J. Scott Chen Hsieh, and T. Yamamoto, "Free from demotivation in EFL writing: the use of online flipped writing instruction," Comput. Assist. Lang. Learn., vol. 33, no. 4, pp. 353-387, May 2020, doi: 10.1080/09588221.2019.1567556.

[27] K. L. Neumann and T. J. Kopcha, "Using Google Docs for Peer-then-Teacher Review on Middle School Students' Writing," Comput. Compos., vol. 54, p. 102524, Dec. 2019, doi: 10.1016/j.compcom.2019.102524.

[28] H. B. Bostanci and Ç. Çavuşoğlu, "Pen-and-paper or online? An academic writing course to teachertrainees," Cogent Educ., vol. 5, no. 1, p. 1482606 , Jan. 2018, doi: 10.1080/2331186X.2018.1482606.
[29] S. Matsuda and P. Gobel, "Anxiety and predictors of performance in the foreign language classroom," System, vol. 32, no. 1, pp. 21-36, Mar. 2004, doi: 10.1016/j.system.2003.08.002.

[30] R. I. Rabadi and A. D. Rabadi, "Do Medical Students Experience Writing Anxiety While Learning English as a Foreign Language?," Psychol. Res. Behav. Manag., vol. Volume 13, pp. 883-893, Oct. 2020, doi: 10.2147/PRBM.S276448.

[31] N. Abdullah Ayash Ezzi, "The Impact of Gender on the Foreign Language Anxiety of the Yemeni University Students," Int. J. Appl. Linguist. Engl. Lit., vol. 1, no. 2, pp. 65-75, Jul. 2012, doi: 10.7575/ijalel.v.1n.2p.65.

[32] N. Jebreil, A. Azizifar, and H. Gowhary, "Investigating the Effect of Anxiety of Male and Female Iranian EFL Learners on their Writing Performance," Procedia - Soc. Behav. Sci., vol. 185, pp. 190-196, May 2015, doi: 10.1016/j.sbspro.2015.03.360.

[33] H. Karatas, B. Alci, M. Bademcioglu, and A. Ergin, "Examination of University Students Foreign Language Classroom Anxiety," Procedia - Soc. Behav. Sci., vol. 232, pp. 396-402, Oct. 2016, doi: 10.1016/j.sbspro.2016.10.055.

[34] A. Umamah, I. Hidayanti, and K. Kurniasih, "Kesulitan Mahasiswa dalam Menulis Teks Eksposisi: Analisa Berbasis Gender," J. Pendidik. Dan Kebud., vol. 4, no. 1, p. 33, Jun. 2019, doi: 10.24832/jpnk.v4i1.1004.

[35] B. Y. Cahyono and U. Widiati, "The teaching of EFL writing in Indonesian context: the state of art," J. Ilmu Pendidik., vol. 13, no. 3, pp. 139-150, 2006.

[36] G. M. Negari and O. T. Rezaabadi, "Too Nervous to Write? The Relationship between Anxiety and EFL Writing," Theory Pract. Lang. Stud., vol. 2, no. 12, pp. 2578-2586, Dec. 2012, doi: 10.4304/tpls.2.12.2578-2586. 